\title{
DISTRIBUTION AND EXCRETION OF RADIOGOLD IN
}

\section{ANIMALS}

BY

\author{
M. R. JEFFREY, H. F. FREUNDLICH, AND DIANA M. BAILEY \\ From the Rheumatism Research Unit, South West Region, Royal National Hospital for Rheumatic Diseases, Bath, \\ and the Physics Department, Bristol General Hospital, Bristol
}

Gold has been used in the treatment of rheumatoid arthritis for about 30 years and, although estimates of its value vary, many clinicians still consider it helpful in some cases. The way in which it produces clinical improvement is unknown and knowledge of its distribution and metabolism in man is fragmentary.

Freyberg, Block, and Levey (1941) and Block, Buchanan, and Freyberg $(1941,1942,1944)$ reported upon the distribution of gold in the major organs of the rat after its injection in several chemical compounds, including some used therapeutically. Since then, sporadic papers have appeared, but the methods used in some studies have subsequently been criticized.

Radioactive isotopes of gold have not been used in this connexion. The isotopes commonly used as radiotherapeutic agents, ${ }^{198} \mathrm{Au}$ and ${ }^{199} \mathrm{Au}$, decay so quickly that useful measurements of their distribution can only be made for a week or two. Since clinical improvement after gold may take several weeks to begin, more extended studies are clearly needed. The isotope ${ }^{195} \mathrm{Au}$ has a half-life of 185 days and would be very suitable for such studies. However, because of its slow decay, retention at the site of injection or elsewhere in the body might produce a radiation hazard. It was necessary, therefore, to seek further information about the distribution of injected gold in animals before considering its use in human investigations. This paper records the distribution of gold in the tissues of rats, guinea-pigs, and rabbits up to 6 months after its injection as calcium aurothiomalate $\left({ }^{195} \mathrm{Au}\right)$. Observations on excretion and on the effects of artificial inflammation are also reported.

\section{Material and Methods}

(1) Animals.-Stock guinea-pigs and albino rats were used, their average weights being about 600 and $250 \mathrm{~g}$. respectively. The rabbits were young does weighing 1.5 to $2 \mathrm{~kg}$. All animals received stock diet and water ad lib. throughout; they ate normally and remained in good health.

(2) Radioactive Gold.-The isotope ${ }^{195} \mathrm{Au}$ was made in the Birmingham University cyclotron and synthesized into calcium aurothiomalate $\left({ }^{195} \mathrm{Au}\right)$ at the Radiochemical Centre, Amersham. ${ }^{195} \mathrm{Au}$ decays by orbital electron capture followed by gamma emission, 90 per cent. of which has an energy of $0.096 \mathrm{MeV}(\mathrm{K} / \mathrm{L}=5.5)$ and 10 per cent. an energy of $0 \cdot 129 \mathrm{MeV}(\mathrm{K} / \mathrm{L}=4 \cdot 7)$, to form the stable isotope ${ }^{195} \mathrm{Pt}$ (Nuclear Data, 1950). The specific activity of the final product was about $9 \mu \mathrm{c}$./mg. gold: it was diluted as needed with 5 per cent. gum acacia.

(3) Procedures.-Gold injections were given by micrometer syringe and intradermal needle into the right quadriceps muscle. Rats received $0.05 \mathrm{ml}$., guinea-pigs $0.10 \mathrm{ml}$., and rabbits $0.20 \mathrm{ml}$. of a suspension containing approximately $6 \mathrm{mg}$. gold and $55 \mu \mathrm{c}$. per $\mathrm{ml}$.

Granuloma pouches were produced by two subcutaneous injections under anaesthesia, 5 days apart, of $15 \mathrm{ml}$. air in the interscapular region of rats, followed through the same needle by $1 \mathrm{ml}$. sterile 1 per cent. croton oil in arachis oil. All the pouches remained sterile and appeared to give the rats no discomfort.

Excreta were collected in screw-topped jars, whose activity was later compared with a standard in a "crown" of Geiger counters (Veall and Vetter, 1952). Carcases were dissolved in fuming nitric acid, transferred to jars, and their activity similarly measured. Organs and tissues were dissolved in fuming nitric acid and the activity in 10-ml. volumes was determined in a scintillation counter. All except the largest specimens could be digested down to this volume. A light precipitate formed after digestion in some specimens with a high calcium content but this was found not to affect estimates of activity. Excess of fat remaining after digestion was removed and added to the appropriate carcase; fat regularly contained only traces of activity.

Inert carrier (gold chloride) was added to all specimens. 
(4) The significance of differences between means was assayed by the " $t$ " test for small samples:

$$
t=\frac{\bar{x}_{1}-\bar{x}_{2}}{\sigma_{\Delta}} \quad \sigma_{\triangle}=\sqrt{\frac{n_{1} s_{1}^{2}+n_{2} s_{2}^{2}}{n_{1}+n_{2}-2} \cdot\left(\frac{n_{1}+n_{2}}{n_{1} n_{2}}\right)}
$$

(5) Recovery Experiments.-Radiogold was injected into five different organs which were then digested and their activity measured; an average of 97.3 per cent. was recovered (range 96.5-98.9). Eight carcases were injected and processed; the mean recovery was $101 \cdot 2$ per cent. (92-5-113). On eight occasions, the radiogold was dropped on to the bottom of a rat cage and the excreta of five untreated animals were then collected from that cage for 4 days. The average recovery of activity was $91 \cdot 2$ per cent. (range $87 \cdot 0-97 \cdot 6$ ).

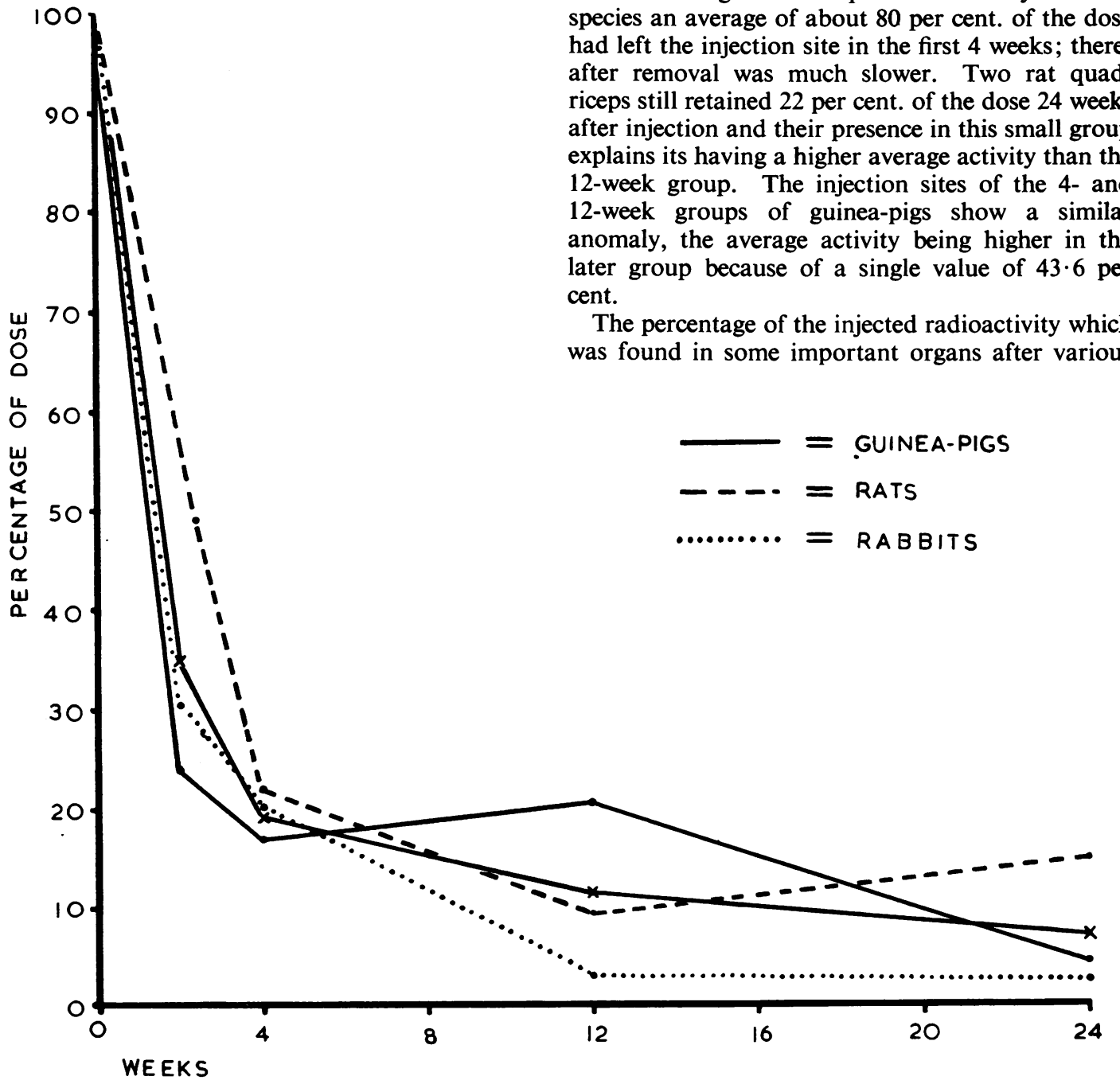

Fig. 1.-Mean percentages of injected dose recovered from site of injection in groups of animals after various intervals. Curve $\mathbf{X}-\mathbf{X}$ represents the mean of the three species.

A further indication of the degree of recovery is given by the groups of animals whose excreta were collected till death. Seven groups of rats gave a mean total recovery of 95.0 per cent. (range 84.9 to 105.2 ), and from eight rabbits the mean was 86.0 per cent. (range $77 \cdot 8$ to $90 \cdot 2$ ).

\section{Results}

\section{Distribution after a Single Injection}

Fig. 1 shows the average percentage of the dose of radioactivity found after various intervals at the site of injection in rats, guinea-pigs, and rabbits. Some activity was present at the injection site of every animal throughout the period of study. In all species an average of about 80 per cent. of the dose had left the injection site in the first 4 weeks; thereafter injection and their presence in this small group explains its having a higher average activity than the 12-week group. The injection sites of the 4- and 12-week groups of guinea-pigs show a similar anomaly, the average activity being higher in the later group because of a single value of 43.6 per ent.

was found in some important organs after various 
intervals is shown in Table I. The rat kidneys might contain up to 10 per cent. of the dose in the first 4 weeks and they remained the organs with the highest content of activity. In guinea-pigs and rabbits, kidney radioactivity was less and was roughly equal to that present in the liver. Spleen and lungs followed the liver in order of content but never contained more than 1 per cent. of the dose in any species.

The total radioactivity remaining in the body at 24 weeks varied from 5 to 10 per cent. in guinea-pigs and rabbits and from 13 to 37 per cent. in rats. As in the case of injection sites, the total body activity was greater in the 24-week group of rats than in the 12-week group. Nearly all organs showed their highest content of activity at 2 weeks; in a few instances the 4-week figure was slightly higher.

Table II (opposite) shows the relative concentrations of radioactivity in various rat tissues, expressed as percentage of the dose per gram of tissue. As the results in guinea-pigs and rabbits were in general the same, detailed tables of these species are omitted; notable differences are mentioned here.
The concentration at injection sites is not given, for the injected material remained fairly localized and any estimate of concentration would depend largely on the amount of inert surrounding muscle excised.

In all species individual results varied widely, so that in these small groups the coefficients of variation lay usually between 25 and 50 per cent. Unless it is stated otherwise, subsequent remarks refer to mean values.

In rats and rabbits the kidney at all times had the highest concentration of activity but after 2 weeks the guinea-pigs' spleen contained concentrations similar to those in their kidneys. The values for rat kidneys were regularly several times higher than those of the other species.

The spleen had the next highest concentration in all species. At 2 weeks, the only other tissues containing more than twice the carcase concentration were rat adrenal and guinea-pig liver. At 4 weeks, the values for rat adrenal, uterus, ovary, pancreas, and lymph gland, and for rabbit adrenal had risen to between three and eight times the carcase concentration. These increases were still

TABLB I

PERCENTAGE OF DOSE IN VARIOUS SITES

\begin{tabular}{|c|c|c|c|c|c|c|c|c|c|c|c|}
\hline \multirow{3}{*}{ Animals } & \multirow{3}{*}{ Site } & & & \multicolumn{8}{|c|}{ No. of Weeks after Injection } \\
\hline & & & & \multicolumn{2}{|c|}{2} & \multicolumn{2}{|c|}{4} & \multicolumn{2}{|c|}{12} & \multicolumn{2}{|c|}{24} \\
\hline & & & & Mean & S.D. & Mean & S.D. & Mean & S.D. & Mean & S.D. \\
\hline \multirow[t]{3}{*}{ Rats } & 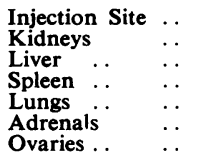 & $\begin{array}{l}\cdots \\
\cdots \\
\cdots \\
\cdots \\
\cdots\end{array}$ & \begin{tabular}{l|l}
$\cdots$ \\
$\cdots$ \\
$\cdots$ \\
$\cdots$ \\
$\cdots$ \\
$\cdots$
\end{tabular} & $\begin{array}{l}47 \cdot 9 \\
6 \cdot 56 \\
0 \cdot 85 \\
0 \cdot 36 \\
0 \cdot 13 \\
0 \cdot 007 \\
0 \cdot 014\end{array}$ & $\begin{array}{l}16 \cdot 9 \\
2 \cdot 3 \\
0 \cdot 29 \\
0 \cdot 15 \\
0 \cdot 06 \\
0 \cdot 004 \\
0 \cdot 007\end{array}$ & $\begin{array}{l}21 \cdot 1 \\
5 \cdot 12 \\
0 \cdot 61 \\
0 \cdot 22 \\
0 \cdot 09 \\
0 \cdot 007 \\
0 \cdot 021\end{array}$ & $\begin{array}{l}11 \cdot 1 \\
1 \cdot 85 \\
0 \cdot 33 \\
0 \cdot 08 \\
0 \cdot 02 \\
0 \cdot 002 \\
0 \cdot 020\end{array}$ & $\begin{array}{l}9 \cdot 3 \\
0.83 \\
0.24 \\
0.06 \\
0.04 \\
0.003 \\
-\end{array}$ & $\begin{array}{l}1 \cdot 9 \\
0 \cdot 12 \\
0 \cdot 07 \\
0 \cdot 013 \\
0 \cdot 024 \\
-*\end{array}$ & $\begin{array}{l}14 \cdot 5 \\
0 \cdot 25 \\
0 \cdot 18 \\
0 \cdot 02 \\
0 \cdot 02 \\
0 \cdot 002 \\
-\end{array}$ & $\begin{array}{l}9 \cdot 3 \\
0 \cdot 15 \\
0 \cdot 09 \\
0 \cdot 01 \\
0 \cdot 01 \\
-*\end{array}$ \\
\hline & Total in Animal & . & $\ldots$ & $67 \cdot 0$ & $14 \cdot 9$ & $37 \cdot 4$ & $11 \cdot 3$ & $13 \cdot 5$ & $2 \cdot 2$ & $24 \cdot 8$ & $9 \cdot 5$ \\
\hline & No. of Animals & $\cdots$ & $\cdots$ & 10 & & 10 & & 5 & & 4 & \\
\hline \multirow[t]{3}{*}{ Guinea-Pigs } & $\begin{array}{ll}\text { Injection Site } & \ldots \\
\text { Kidneys } & \ldots \\
\text { Liver } \quad . & \ldots \\
\text { Spleen } \ldots & \ldots \\
\text { Lungs . } & \ldots \\
\text { Adrenals } & \ldots\end{array}$ & $\begin{array}{l}\ldots \\
\cdots \\
\cdots \\
\cdots \\
\cdots\end{array}$ & \begin{tabular}{l|}
$\cdots$ \\
$\cdots$ \\
$\cdots$ \\
$\cdots$ \\
$\cdots$
\end{tabular} & $\begin{array}{l}23 \cdot 9 \\
4 \cdot 00 \\
3 \cdot 66 \\
0 \cdot 20 \\
0 \cdot 09 \\
0 \cdot 018\end{array}$ & $\begin{array}{l}6.6 \\
1.1 \\
0.93 \\
0.04 \\
0.03 \\
0.006\end{array}$ & $\begin{array}{l}16 \cdot 2 \\
0 \cdot 62 \\
0 \cdot 84 \\
0 \cdot 11 \\
0 \cdot 04 \\
0 \cdot 01\end{array}$ & $\begin{array}{l}1 \cdot 2 \\
0 \cdot 57 \\
0 \cdot 52 \\
0 \cdot 03 \\
0.009 \\
\end{array}$ & $\begin{array}{l}19 \cdot 9 \\
0 \cdot 24 \\
0 \cdot 29 \\
0 \cdot 041 \\
0 \cdot 016 \\
0 \cdot 006\end{array}$ & $\begin{array}{l}16 \cdot 1 \\
0 \cdot 13 \\
0 \cdot 10 \\
0 \cdot 10 \\
0 \cdot 005 \\
-*\end{array}$ & $\begin{array}{l}4 \cdot 5 \\
0 \cdot 05 \\
0 \cdot 08 \\
0 \cdot 007 \\
0 \cdot 006 \\
0 \cdot 006\end{array}$ & $\begin{array}{l}2 \cdot 8 \\
0 \cdot 04 \\
0 \cdot 07 \\
0 \cdot 003 \\
0 \cdot 005 \\
-*\end{array}$ \\
\hline & Total in Animal & . & $\ldots$ & $49 \cdot 6$ & $4 \cdot 8$ & $28 \cdot 5$ & $2 \cdot 1$ & $26 \cdot 4$ & $16 \cdot 2$ & $6 \cdot 2$ & $2 \cdot 2$ \\
\hline & No. of Animals & . & $\cdots$ & 4 & & 4 & & 4 & & 4 & \\
\hline \multirow[t]{3}{*}{ Rabbits } & $\begin{array}{ll}\text { Injection Site. . } \\
\text { Kidneys } & \ldots \\
\text { Liver } \ldots & \ldots \\
\text { Spleen } \ldots & \ldots \\
\text { Lungs } \ldots & \ldots \\
\text { Adrenals } & \ldots \\
\text { Ovaries } & \ldots\end{array}$ & $\begin{array}{l}\cdots \\
\cdots \\
\cdots \\
\cdots \\
\cdots\end{array}$ & \begin{tabular}{l|}
$\cdots$ \\
$\cdots$ \\
$\cdots$ \\
$\cdots$ \\
$\cdots$ \\
$\cdots$
\end{tabular} & $\begin{array}{l}30 \cdot 2 \\
3 \cdot 69 \\
2 \cdot 67 \\
0 \cdot 07 \\
0 \cdot 29 \\
0 \cdot 005 \\
0 \cdot 008\end{array}$ & $\begin{array}{l}11 \cdot 1 \\
0 \cdot 36 \\
0 \cdot 66 \\
0 \cdot 04 \\
0 \cdot 03 \\
0 \cdot 001 \\
0 \cdot 002\end{array}$ & $\begin{array}{l}18 \cdot 9 \\
2 \cdot 05 \\
2 \cdot 28 \\
0 \cdot 05 \\
0 \cdot 13 \\
0 \cdot 003 \\
0 \cdot 006\end{array}$ & $\begin{array}{l}8 \cdot 4 \\
0 \cdot 7 \\
1 \cdot 0 \\
0 \cdot 03 \\
0 \cdot 05 \\
0 \cdot 001 \\
0 \cdot 001\end{array}$ & $\begin{array}{l}2 \cdot 8 \\
0 \cdot 86 \\
1 \cdot 12 \\
0 \cdot 01 \\
0 \cdot 02 \\
0 \cdot 001 \\
0 \cdot 003\end{array}$ & & $\begin{array}{l}2.3 \\
0.15 \\
0.06 \\
0.004 \\
0.006 \\
<0.001 \\
<0.001\end{array}$ & \\
\hline & Total in Animal & . & $\cdots$ & $61 \cdot 7$ & $7 \cdot 8$ & $42 \cdot 9$ & $7 \cdot 4$ & $14 \cdot 45$ & & $12 \cdot 1$ & \\
\hline & No. of Animals & . & . & 3 & & 3 & & 2 & & 1 & \\
\hline
\end{tabular}


TABLE II

PERCENTAGE OF DOSE PER GRAM OF TISSUE IN RATS

\begin{tabular}{|c|c|c|c|c|c|c|c|c|c|c|c|}
\hline & \multirow{3}{*}{\multicolumn{2}{|c|}{ Site }} & & \multicolumn{8}{|c|}{ No. of Weeks after Injection } \\
\hline & & & & \multicolumn{2}{|c|}{2} & \multicolumn{2}{|c|}{4} & \multicolumn{2}{|c|}{12} & \multicolumn{2}{|c|}{24} \\
\hline & & & & Mean & S.D. & Mean & S.D. & Mean & S.D. & Mean & S.D. \\
\hline $\begin{array}{l}\text { Kidney } \\
\text { Liver } \\
\text { Spleen } \\
\text { Lung } \\
\text { Submandibu } \\
\text { Adrenal } \\
\text { Heart } \\
\text { Pancreas } \\
\text { Brain } \\
\text { Pituitary } \\
\text { Testes } \\
\text { Ovary } \\
\text { Uterus } \\
\text { Skin } \\
\text { Femur } \\
\text { Knee joint } \\
\text { Lymph glan } \\
\text { Jejunum } \\
\text { Ileum } \\
\text { Colon } \\
\text { Quadriceps }\end{array}$ & $\begin{array}{l}\ldots \\
\ldots \\
\cdots \\
\text { ular g } \\
\ldots \\
\ldots \\
\ldots \\
\ldots \\
\ldots \\
\ldots \\
\ldots \\
\ldots \\
\text { nd } \\
\ldots \\
\ldots \\
\text { muscl }\end{array}$ & $\begin{array}{c}\ldots \\
\ldots \\
\cdots \\
\text { land } \\
\ldots \\
\ldots \\
\ldots \\
\ldots \\
\ldots \\
\ldots \\
\cdots \\
\ldots \\
\ldots \\
\ldots \\
\cdots\end{array}$ & 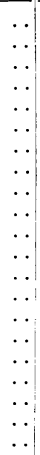 & $\begin{array}{l}2.83 \\
0.062 \\
0.362 \\
0.077 \dagger \\
0.061 \dagger \\
0.113 \\
0.026 \dagger \\
0.082 \dagger \\
0.004 \dagger \\
0.033 \\
-- \\
0.103 \dagger \\
0.112 \dagger \\
0.051 \dagger \\
0.026 \dagger \\
0.048 \dagger \\
0.102 \dagger \\
0.075 \dagger \\
0.059 \dagger \\
0.074 \dagger \\
0.012 \dagger\end{array}$ & $\begin{array}{l}1.0 \\
0.024 \\
0.12 \\
0.031 \\
0.031 \\
0.049 \\
0.006 \\
0.036 \\
0.002 \\
-. \\
0.06 \\
0.016 \\
0.006 \\
0.008 \\
0.027 \\
0.033 \\
0.021 \\
0.025 \\
0.023 \\
0.001\end{array}$ & $\begin{array}{l}2.46 \\
0.050 \\
0.310 \\
0.053 \\
0.048 \\
0.260 \\
0.024 \\
0.116 \dagger \\
0.004 \\
0.057 \\
0.116 \dagger \\
0.25 \\
0.040 \\
0.019 \\
0.030 \\
0.130 \\
0.055 \dagger \\
0.058 \dagger \\
0.053 \dagger \\
0.012\end{array}$ & $\begin{array}{l}1.0 \\
0.04 \\
0.163 \\
0.017 \\
0.023 \\
0.023 \\
0.006 \\
0.055 \\
0.004 \\
-* \\
0.043 \\
0.28 \\
0.022 \\
0.007 \\
0.008 \\
0.025 \\
0.022 \\
0.021 \\
0.004\end{array}$ & $\begin{array}{l}0.321 \\
0.016 \\
0.068 \\
0.025 \\
0.008 \\
0.054 \\
0.006 \\
0.035 \\
0.002 \\
0 \\
0.014 \\
- \\
0.007 \\
0.007 \\
0.006 \\
0.024 \\
- \\
- \\
0.002\end{array}$ & $\begin{array}{l}0.066 \\
0.005 \\
0.010 \\
0.010 \\
-* \\
0.002 \\
0.014 \\
0.001 \\
\overline{0.006} \\
- \\
0.001 \\
0.003 \\
0.003 \\
\overline{-} \\
\overline{-} \\
0.001\end{array}$ & $\begin{array}{c}0.086 \\
0.008 \\
0.032 \\
0.006 \\
0.005 \\
0.008 \\
0.003 \\
0.006 \\
0.002 \\
0 \\
0.012 \\
- \\
0.006 \\
0.0 \\
0.007 \\
0.022 \\
0.007 \\
0.003 \\
0.006 \\
0.001\end{array}$ & $\begin{array}{l}0.056 \\
0.004 \\
0.016 \\
0.004 \\
0.003 \\
\overline{0.001} \\
\overline{0.0} \\
0.002 \\
\overline{0.004} \\
\overline{-} \\
0.003 \\
\overline{0.011} \\
\overline{0.003} \\
0.005 \\
0.004 \\
0.001\end{array}$ \\
\hline Total Carcas & se & $\ldots$ & $\cdots$ & 0.054 & 0.019 & 0.032 & $0 \cdot 010$ & 0.009 & 0.003 & 0.007 & 0.005 \\
\hline Number of & Anin & nals & $\cdots$ & 10 & & 10 & & 5 & & 4 & \\
\hline
\end{tabular}

evident at 12 weeks in rat adrenal and pancreas and up to 24 weeks in rat lymph glands.

Average values in other tissues were never more than three times the carcase concentration. Activity was not concentrated by intestine or reproductive organs and the relatively large quantities of activity present in the liver (Table I) were due simply to its size and not to any special concentrating ability. Brain and voluntary muscle regularly contained concentrations of activity well below the carcase level. There was no evident localization of activity in joint tissues.

\section{Excretion after a Single Injection}

Excreta were collected from some rats, in groups of five, and from some rabbits individually. The daily rate of excretion is shown in Fig. 2 (overleaf), and the average quantities excreted appear in Table III (overleaf).

The rate of excretion reached its maximum about 6 days after injection, when up to 3 per cent. of the dose was excreted daily, and thereafter declined. Both species excreted about 40 per cent. of the dose in 4 weeks, the rates of excretion being remarkably similar.

\section{Effect of Multiple or Repeated Doses}

(1) Multiple Doses.-In two rabbits the quantity of radiogold usually given in one injection was divided into four parts and given into each triceps and quadriceps muscle. When the rabbits were killed after 2 weeks the distribution of activity did not differ from that in animals given a single injection. All the muscles contained between 22 and 36 per cent. of the activity injected into them. Both the animals excreted about 34 per cent. of the dose in the 2 weeks after injection.

(2) Single Active Dose followed by Inert Gold Injections.-To observe any possible modifying effects of subsequent injections upon the fate of the first injection, four rats were given the usual dose of radiogold followed by three weekly injections of the same quantity of inert calcium aurothiomalate. Excreta were collected for 6 weeks and the animals were killed at 12 weeks. This group retained slightly more activity at the injection site and in the whole animal (means 14.0 and 18.4 per cent.) compared with the rats which had received only a single radiogold injection (means $9 \cdot 3$ and 13.5 per cent.); the kidneys, on the other hand, contained slightly less $(0.60$ compared with 0.83 per cent.). None of these differences is statistically significant and the content and concentration of activity in other tissues were closely similar to those found in the rats given a single radiogold injection.

Excretion of the initial radiogold injection was unaffected by the subsequent giving of inert gold (Table III). The total 6 weeks' excretion was 46.8 per cent., almost the same as the average for rats given a single active injection only. 


\section{INJECTIONS}

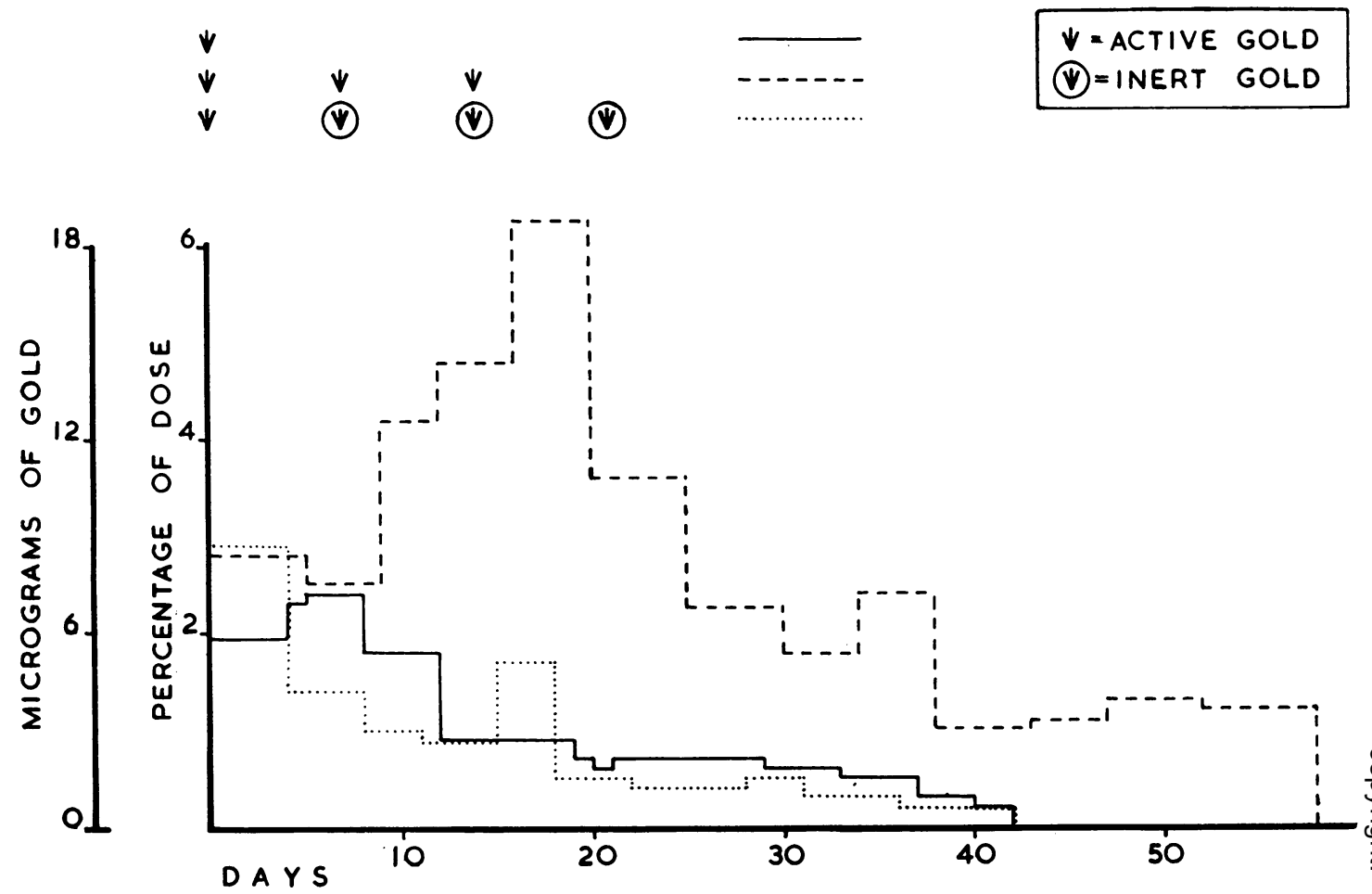

CORRESPONDING

\section{LINES}

FIG. 2.-Excretion of radioactivity by groups of rats after radiogold injection, shown as mean percentage of dose excreted per rat per day. Results are given after a single dose of radiogold, after three doses at weekly intervals, and after one radioactive dose followed by three weekly doses of the same quantity of inert calcium aurothiomalate.

TABLE III

PERCENTAGE OF INJECTED RADIOGOLD RECOVERED IN EXCRETA

\begin{tabular}{|c|c|c|c|c|c|c|c|c|}
\hline \multirow{3}{*}{ Animal } & \multirow{3}{*}{\multicolumn{2}{|c|}{ Dosage }} & \multicolumn{6}{|c|}{ No. of Weeks after Injection } \\
\hline & & & \multicolumn{2}{|c|}{$0-2$} & \multicolumn{2}{|c|}{$2-4$} & \multicolumn{2}{|c|}{$4-6$} \\
\hline & & & Mean & S.D. & Mean & S.D. & Mean & S.D. \\
\hline \multirow[t]{2}{*}{ Rabbit } & Single Dose of Radiogold & $\ldots$ & $28 \cdot 0$ & $5 \cdot 9$ & $13 \cdot 1$ & $3 \cdot 0$ & - & - \\
\hline & No. of Animals & . & 8 & & 3 & & - & \\
\hline \multirow{8}{*}{ Rat } & (i) Single Injection of Radiogo & $\cdots$ & $26 \cdot 2$ & & $12 \cdot 7$ & & $6 \cdot 1$ & \\
\hline & No. of Animals & $\cdots$ & 25 & & 15 & & 5 & \\
\hline & $\begin{array}{l}\text { (ii) Single Injection of Radiogold } \\
\text { of Inert Gold .. }\end{array}$ & then Three & $28 \cdot 5$ & & $13 \cdot 4$ & & $4 \cdot 9$ & \\
\hline & No. of Animals & $\cdots$ & 5 & & 5 & & 5 & \\
\hline & $\begin{array}{l}\text { (iii) Granulowa Pouch } \\
\text { (Radiogold I week later) }\end{array}$ & .. & $41 \cdot 3$ & & $26 \cdot 1$ & & - & \\
\hline & No. of Animals & . & 10 & & 5 & & - & \\
\hline & $\begin{array}{l}\text { (iv) Granuloma Pouch } \\
\text { (Radiogola' } 4 \text { weeks later) }\end{array}$ & $\ldots$ & $33 \cdot 0$ & & $12 \cdot 2$ & & - & \\
\hline & No. of Animals & $\cdots$ & 4 & & 4 & & - & \\
\hline
\end{tabular}

Excreta were collected from groups of four or five rats and singly from rabbits: standard deviations are therefore only given for rabbits. 
(3) Three Weekly Injections of Radiogold.-Five rats were given three injections of radiogold at weekly intervals into the same quadriceps muscle. Excreta were collected for 6 weeks and the animals were killed after 12 weeks. At the injection site an average of 13.7 per cent. of the total dose was recovered, compared with $9 \cdot 3$ per cent. in rats given a single injection, and the whole animals contained 25.6 per cent. of the dose compared with 13.5 per cent. Nearly all the tissues of the three-dose rats contained concentrations of activity two or three times greater than those found in single-dose animals, but the pattern of distribution was unaltered. In tissues other than kidney, spleen, and pancreas, the concentration of activity was less than three times the general carcase level; activity in the brain was well below that in the carcase.

In 6 weeks, 49.6 per cent. of the total injected activity was excreted, almost the same as the average after a single dose. The course of excretion, depicted in Fig. 2, shows that stepwise increases in output followed each injection. The rate of excretion fell rapidly when injections ceased but throughout the period of study remained considerably higher than that observed after a single dose.

\section{Effect of Artificial Inflammation}

Granuloma pouches were produced in rats and one week after the second irritant injection some of them received a single dose of radiogold. Groups were killed 2, 4, and 12 weeks after the gold injection. Another group was given radiogold 4 weeks after the second irritant injection and was killed 4 weeks later. Table IV summarizes the distribution of the radioactivity; Table $\mathrm{V}$ (overleaf) shows the relative concentrations in different tissues.

(1) Radiogold One Week after the Second Irritant Injection.--In this group of animals, activity left the site of injection much more quickly than in normal animals. All the differences are significant $(p=<0.01$ at 2 and 4 weeks, and $0.02>p>0.01$ at 12 weeks). An average of 15 per cent. of the dose remained at the injection site after 2 weeks compared with 48 per cent. in normal rats. The activity in the kidneys, liver, and spleen was greater in the rats with pouches than in normal animals, but only in the case of the kidneys at 12 weeks did the difference reach the significance level $(p=0.05)$. The total activity present in the body at 2 weeks was reduced in the "pouch" rats $(p=<0.01)$, but at 4 and 12 weeks the differences were unimportant.

The granuloma pouch contained about 1 per cent. of the injected activity at 2 and 4 weeks, the highest single value being 2.5 per cent. In four animals the quantity of activity present in the wall and the fluid content of the pouch was compared and appeared roughly equal.

The relative concentrations of radioactivity in various tissues appear in Table V. Comparison with normal animals (Table II) reveals that the rats with pouches had higher concentrations in the kidney, liver, spleen, and heart at 2, 4, and 12 weeks. The increase was never greater than two-fold and only reached the significance level $(p=0.05)$ in the case of the spleen at 2 and 4 weeks. The carcases of the "pouch" animals had a higher concentration of activity after 4 and 12 weeks ( $p=<0.01$ in each case). There was no increase in intestinal or reproductive tissues.

TABLE IV

PERCENTAGE OF INJECTED RADIOACTIVITY IN ORGANS OF RATS WITH GRANULOMA POUCHES

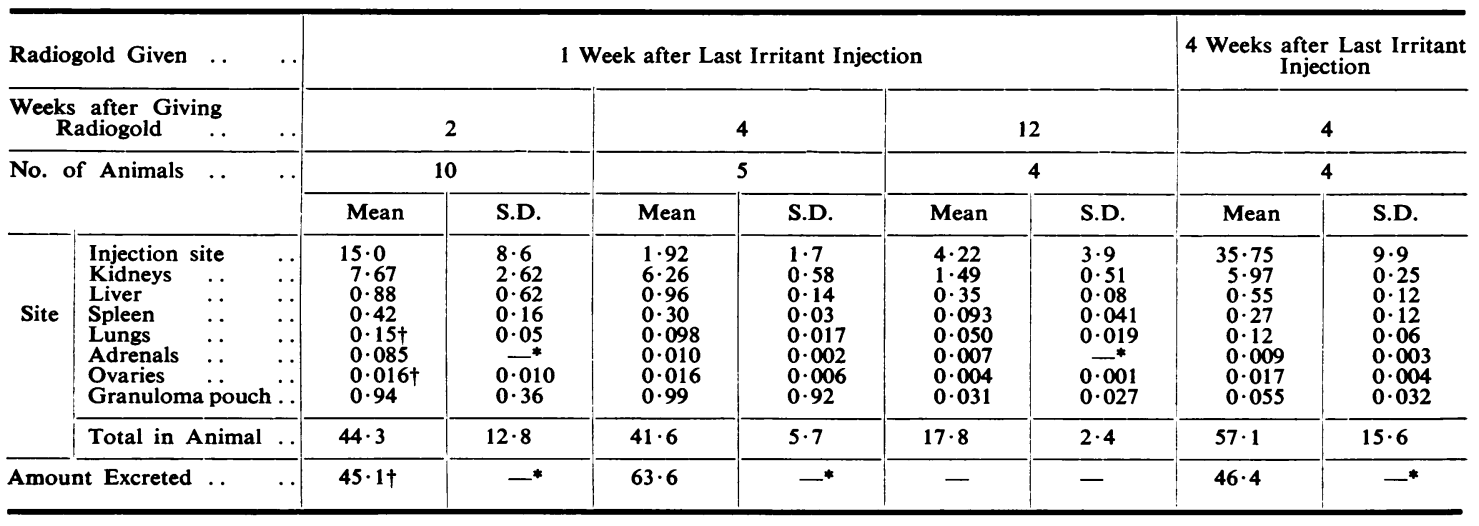


TABLE $\mathrm{V}$

RELATIVE CONCENTRATIONS OF INJECTED RADIOGOLD IN RATS WITH GRANULOMA POUCHES

\begin{tabular}{|c|c|c|c|c|c|c|c|c|c|c|c|}
\hline \multicolumn{4}{|c|}{ Radiogold Given .. } & \multicolumn{6}{|c|}{1 Week after Last Irritant Injection } & \multicolumn{2}{|c|}{$\begin{array}{l}4 \text { Weeks after Last } \\
\text { Irritant Injection }\end{array}$} \\
\hline \multicolumn{4}{|c|}{$\begin{array}{c}\text { Weeks after giving } \\
\text { Radiogold }\end{array}$} & \multicolumn{2}{|c|}{2} & \multicolumn{2}{|c|}{4} & \multicolumn{2}{|c|}{12} & \multicolumn{2}{|c|}{4} \\
\hline \multirow[t]{2}{*}{ No. of } & \multirow[t]{2}{*}{ Animals } & \multirow[t]{2}{*}{$\cdots$} & \multirow[t]{2}{*}{$\cdots$} & \multicolumn{2}{|c|}{10} & \multicolumn{2}{|c|}{5} & \multicolumn{2}{|c|}{4} & \multicolumn{2}{|c|}{4} \\
\hline & & & & Mean & S.D. & Mean & S.D. & Mean & S.D. & Mean & S.D. \\
\hline Site & $\begin{array}{l}\text { Kidney } \\
\text { Liver } \\
\text { Spleen } \\
\text { Lung } \\
\text { Heart } \\
\text { Adrenal } \\
\text { Pancreas } \\
\text { Submandib } \\
\text { Lymph gla } \\
\text { Ovary } \\
\text { Uterus } \\
\text { Jejunum } \\
\text { Ileum } \\
\text { Colon } \\
\text { Brain } \\
\text { Pituitary } \\
\text { Skin } \\
\text { Shaft of fe } \\
\text { Quadriceps } \\
\text { Granuloma }\end{array}$ & 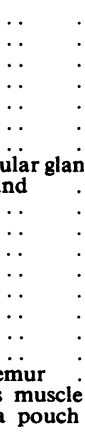 & $\begin{array}{l}\cdot \\
. \\
. \\
. \\
. \\
\dot{0} \\
. \\
. \\
. \\
. \\
. \\
. \\
.\end{array}$ & $\begin{array}{l}3.84 \\
0.089 \\
0.514 \\
0.098 \dagger \\
0.042 \dagger \\
0.121 \\
0.055 \dagger \\
0.091 \dagger \\
0.095 \dagger \\
0.066 \dagger \\
0.056 \dagger \\
0.040 \dagger \\
0.058 \dagger \\
- \\
- \\
- \\
- \\
0.206\end{array}$ & $\begin{array}{l}1.41 \\
0.071 \\
0.180 \\
0.012 \\
0.008 \\
0.051 \\
0.036 \\
\overline{0} 045 \\
0.053 \\
0.050 \\
0.011 \\
0.015 \\
0.019 \\
- \\
- \\
- \\
- \\
0.260\end{array}$ & $\begin{array}{l}2.91 \\
0.086 \\
0.418 \\
0.070 \\
0.030 \\
0.146 \\
0.136 \\
0.045 \\
0.187 \\
0.109 \\
- \\
- \\
- \\
0.094 \\
0.005 \\
0.061 \\
0.024 \\
0.014 \\
0.183\end{array}$ & $\begin{array}{l}0.35 \\
0.010 \\
0.063 \\
0.015 \\
0.006 \\
0.021 \\
0.022 \\
0.009 \\
0.025 \\
- \\
- \\
-\overline{0} \\
0.001 \\
0.034 \\
0.007 \\
0.005 \\
0.170\end{array}$ & $\begin{array}{l}0.710 \\
0.027 \\
0.120 \\
0.020 \\
0.009 \\
0.084 \\
0.075 \\
0.025 \\
0.056 \\
0.026 \\
- \\
- \\
- \\
0.003 \\
0 \\
0.016 \\
0.005 \\
0.005 \\
0.074\end{array}$ & $\begin{array}{l}0.32 \\
0.006 \\
0.047 \\
0.005 \\
0.002 \\
0.032 \\
0.031 \\
0.014 \\
- \\
- \\
- \\
0.001 \\
0.009 \\
0.004 \\
0.005 \\
0.069\end{array}$ & $\begin{array}{l}2.81 \\
0.043 \\
0.243 \\
0.057 \\
0.023 \\
0.100 \\
0.108 \\
0.038 \\
0.121 \\
0.080 \\
0.193 \\
0.045 \\
0.038 \\
0.038 \\
0.003 \\
0.071 \\
0.049 \\
0.012 \\
0.010 \\
0.099\end{array}$ & $\begin{array}{l}0.48 \\
0.006 \\
0.22 \\
0.019 \\
0.004 \\
0.030 \\
0.070 \\
0.010 \\
0.042 \\
0.014 \\
0.21 \\
0.013 \\
0.007 \\
0.011 \\
0.001 \\
0.036 \\
0.011 \\
0.001 \\
0.005 \\
0.028\end{array}$ \\
\hline Total & Carcase & $\ldots$ &. & 0.059 & 0.024 & $0 \cdot 103$ & .015 & 0.038 & 0.012 & 0.047 & 0.019 \\
\hline
\end{tabular}

Figures denote percentage of dose per $\mathrm{g}$. tissue.

* = Pooled specimens.

$\dagger=$ Five specimens only.

Excretion of the injected activity was followed up to 4 weeks (Table III). In the first and second 2-week periods, the rats with pouches excreted 13 and 15 per cent. more of the dose than the averages for healthy animals: these differences could easily be fortuitous $(0 \cdot 2>p>0 \cdot 1$ for the first 2 weeks). The average maximum rate of excretion, $3 \cdot 7$ per cent. of the dose per day, occurred within 4 days of injection and was higher than in normal rats ( 2.8 per cent. per day).

(2) Radiogold Four Weeks after the Second Irritant Injection.-In these four rats, killed 4 weeks after the dose of radiogold, more activity was present at the site of injection and in the kidneys than in normal rats after the same interval. The difference could readily be due to chance with such a small sample and other tissues showed no material alteration in content or concentration. The total recovery of activity from the animal bodies was significantly greater than normal in these "pouch" rats. Their excretion was also slightly but insignificantly higher.

\section{Discussion}

This investigation, in which the distribution and excretion of gold in animals were estimated by measuring radioactivity after the injection of radiogold as calcium aurothiomalate $\left({ }^{195} \mathrm{Au}\right)$, has confirmed in general the results of previous workers.
Block and others $(1941,1942,1944)$ reported upono the distribution of gold in some major organs of the rat after the injection of various compounds, using a chemical method of estimation (Block and Buchanan, 1940, 1942). Calcium aurothiomalate was one of the compounds studied and we also used it for the present investigation, since it is the gold preparation which we usually employ therapeutically. The two series are not, however, wholly comparable, for we gave a single dose of a suspension in an aqueous medium, containing $0.3 \mathrm{mg}$. gold, whereas Block and others (1944) gave a daily dose of an oily suspension containing $1 \mathrm{mg}$. gold for 14 days and expressed their results in terms of days after the last injection.

Because of the different modes of administration, it might be expected that Block's results 15 days after ceasing injections would lie between our figures obtained 2 and 4 weeks after a single dose. In fact, the proportions of the dose recovered from the whole body, injection site, liver, and spleen of Block's rats are close to our figures for 4 weeks; their kidneys, however, contained considerably less gold than our rats at 4 weeks; 12 weeks after injection, when the effects of different dosages were presumably less important, the average total body content was virtually identical in the two series, being about 13 per cent. of the dose. 
In our series, the distribution of radioactivity in the tissues was essentially the same in rats, guineapigs, and rabbits, and the excretion by rats and rabbits was remarkably similar. The lack of differences between species in handling doses of gold equivalent to those used in man somewhat enhances confidence in predictions from these experiments of radiation hazards from the use of ${ }^{195} \mathrm{Au}$ in man.

It appeared at first that removal of activity from the site of injection might follow a simple exponential curve, but after 4 weeks, when about 80 per cent. of the dose had left the injection site, the rate of removal slowed greatly (Fig. 1). The reason for this is obscure. One possibility, that the injected material became encapsulated by fibrous tissue, can be excluded, since autoradiographs show no evidence of fibrosis around the foci of activity 6 months after injection. In two rats, four guinea-pigs, and one rabbit, killed after 24 weeks, between 2 and 9 per cent. of the dose remained at the injection site and a further 1 to 10 per cent. was recovered from the other tissues of the body. In two rats, however, 22 per cent. of the dose was still present at the injection site 24 weeks later. The possibility of this persistence in the injected muscle may well limit the use of this isotope in man.

Of the organs and tissues examined, the kidneys were at all times pre-eminent in content and concentration of radioactivity. Presumably this indicates their predominant role in excretion. We did not estimate urinary and faecal elimination of radioactivity separately, but the concentration of activity in the wall of the gut was never more than twice the average concentration in the carcase tissues. It would seem that faecal elimination was less important in our rats than in Block's; about three-quarters of the gold excreted by his rats during the 2 weeks of injections was contained in the faeces.

No other organ contained any major quantity of activity. Most tissues had attained their highest concentration of activity 2 weeks after injection, the level at 4 weeks being slightly lower; in a few tissues, the peak was not reached until 4 weeks. By 24 weeks, the kidney tissue was the only one to contain a concentration of activity markedly different from the carcase level. In the early weeks after injection, lymphoid tissue (spleen and lymph gland) and, to a lesser extent, the parenchymatous organs in general appeared to concentrate activity slightly. There was no special concentration by joint tissues; the brain and voluntary muscle contained less than the general average.

Excretion was closely similar in our rats and rabbits, about 40 per cent. being eliminated in the 4 weeks after injection. Block's rats excreted
40 per cent. of the total dose during the 14 days in which they had daily injections. Although we did not measure excretion beyond 6 weeks, the continuing slow mobilization of gold from the injection site might be expected to lead to the excretion of small amounts for long periods. Freyberg and others (1941), in fact, were able to detect gold in the urine for many months after its therapeutic injection in man.

The distribution of a single dose of radiogold was not altered by subsequent administration of the same compound of inert gold nor was excretion impaired. Thus there is nothing to suggest that gold therapy after the use of radiogold for investigations would increase the radiation hazard in man. With the doses employed, no upper limit to excretion was demonstrated. Three weekly injections were each followed by a proportionate increase in output. If the figures for excretion after a single dose are used to make an estimate of the excretion to be expected after three weekly doses, calculation shows that about 43 per cent. should be eliminated in the first 6 weeks. In fact, the rats given three weekly doses excreted 49.6 per cent. in this time, suggesting that excretion is proportional to total body content, and confirming the absence of an upper limit to excretion at this dosage level.

Since no animal equivalent to rheumatoid arthritis exists, we chose the granuloma pouch technique of Rindani and Selye (1953) to study the possible effects of granulomatous inflammation upon radiogold distribution. The technique produces a sac composed of granulation tissue. In the early stages, the wall consists of a thin necrotic zone outside which is a thicker layer of proliferating fibroblasts and capillaries with a light round cell infiltration. The necrotic layer and the round cells in time disappear, leaving a wall of young fibrous tissue containing some capillaries and residual fat lobules.

In its early stages the presence of this lesion appeared to accelerate the metabolism of gold. When radiogold was given a week after the last irritant injection, the rates of excretion of radioactivity and its removal from the site of injection were considerably enhanced. The increased rates only obtained for the first 2 weeks, however, the levels thereafter returning to those observed in normal animals. When gold was given a month after the production of inflammation, the augmented rates were not observed. Human rheumatoid arthritis, in which inflammation is chronic and often quite mild, might thus be expected to influence the radiation hazard from ${ }^{195} \mathrm{Au}$ relatively little; if anything, its tendency would be to reduce the hazard. 
The pattern of radiogold distribution was not altered by the presence of inflammation. In most tissues, the average content of activity was higher than in normal animals by about 50 per cent., though individual differences could readily have been fortuitous. The inflammatory tissue of the granuloma pouches contained material quantities of activity, the concentration per gram of tissue at 2 weeks being higher than that of all other tissues except kidney and spleen. This perhaps favours the idea that gold exerts a local effect on inflamed tissues rather than an indirect general effect.

\section{Summary}

Calcium aurothiomalate $\left({ }^{195} \mathrm{Au}\right)$ was given intramuscularly to rats, guinea-pigs, and rabbits, in doses equivalent in terms of body weight to those used in man.

The distribution of radioactivity in important tissues was followed for periods up to 24 weeks and the excretion for shorter periods.

Variations among the animals of one species were considerable: major differences between species were not apparent.

Four weeks after injection, an average of 20 per cent. of the dose remained at the site of injection and about 40 per cent. had been excreted. Up to 22 per cent. might, however, be found at the site of injection after 24 weeks.

The kidneys concentrated activity considerably, and other tissues to a much less extent.

Distribution and excretion were unaffected by splitting the dose of radiogold or by giving inert gold subsequently. A stepwise increase of excretion followed three weekly radiogold injections; the pattern of distribution was unaltered.

The presence of a recent granuloma pouch appeared to accelerate absorption of radiogold from the site of injection and its excretion.

We wish to thank the Medical Research Council for a grant to purchase the radiogold. We are much indebted to Dr. J. C. Charlton, who synthesized the required compound, and to Dr. D. P. Page Thomas, who was responsible for the care and injection of many of the animals. We also thank Dr. G. D. Kersley for encouragement and advice, Dr. G. Herdan for statistical guidance, and Mr. D. Tovey for invaluable assistance.

\section{REFERENCES}

Block, W. D., and Buchanan, O. H. (1940). J. biol. Chem., 136, 379. Block, W. (1942). J. Lab. clin. Med., 28, 118.

$-Z$, and Freyberg, R. H. (1941). J. Pharmacol., 73, 200.
$Z,-$ (1942). Ibid., 76, 355.
Freyberg, R. H., Block, W. D., and Levey, S. (1941). J. clin. Invest.,

“Nuclear Data". Circular of the U.S. National Bureau of Standards, Sept. 1950 , p. 499.
Rindani, T. H., and Selye, H. (1953). Brit. J. exp. Path., 34, 674. Veall, N., and Vetter, H. (1952). Brit. J. Radiol., 25, 85.

\section{Distribution et excrétion d'or radioactif chez les animaux}

\section{RÉSUMÉ}

On a administré par voie intramusculaire de l'aurothiomalate de calcium $\left({ }^{195} \mathrm{Au}\right)$ à des rats, des cobayes et des lapins, en doses équivalentes, relativement au poids du corps, à celles employés chez l'homme.

$\mathrm{La}$ distribution de la radioactivité dans les tissus importants fut observée durant des périodes allant jusqu'à 24 semaines et l'excrétion durant des périodes plus courtes.

Les variations parmi les animaux d'une même espèce furent considérables; des différences majeures entre les espèces ne furent pas apparentes.

Quatre semaines après l'injection, une moyenne de $20 \%$ de la dose se trouvait encore au point d'injection et environ $40 \%$ avait été excrétée. On pouvait cependant trouver jusqu'à $22 \%$ au point d'injection après 24 semaines.

Il y avait une considérable concentration de radioactivité dans les reins et beaucoup moins dans les autres tissus.

La distribution et l'excrétion ne furent pas affectées par la division des doses d'or radioactif ou par l'administration subséquente d'or inerte. Trois injections hebdomadaires d'or radioactif provoquèrent une augmentation au pas de l'excrétion; le tableau de distribution ne fut pas modifié.

La présence d'une poche granulomateuse récente semblait accélerer l'absorption de l'or radioactif du point d'infection, ainsi que son excrétion.

\section{Distribución y excreción de oro radioactivo en animeles}

\section{SUMARIO}

Aurotiomalato de calcio $\left({ }^{195} \mathrm{Au}\right)$ fué administrado por vía intramuscular a ratas, cobayos y conejos, en dosis equivalentes, relativamente al peso del cuerpo, a las empleadas en el hombre.

La distribución de la radioactividad en los tejidos importantes fué observada durante períodos extendiéndose hasta 24 semanas, y la excreción durante períodos más cortos.

Las variaciones entre los animales de la misma especie fueron considerables; diferencias mayores entre especies no fueron aparentes.

Cuatro semanas después de la inyección, un promedio del $20 \%$ de la dosis encontrábase todavía en el sitio de la inyección, y cerca del $40 \%$ habiendo sido eliminado. Fué sin embargo posible encontrar hasta a un $22 \%$ en el sitio de la inyección al cabo de 24 semanas.

Hubo una considerable concentración de radioactividad en los riñones y mucha menos en los demás tejidos.

La distribución y la excreción no fueron afectadas por la división de las dosis de oro radioactivo o par la administración subsecuente de oro inerte. Tres inyecciones semanales de oro radioactivo provocaron paso a paso un aumento de la excreción, sin modificar el cuadro de distribución.

La presencia de una bolsa granulomatosa reciente parecía accelerar la absorpción del or radioactivo de sitio de inyección, así como su excreción. 